Article

\title{
COVID-19 and the Digital Transformation of Education: What Are We Learning on 4IR in South Africa?
}

\author{
David Mhlanga * (1) and Tankiso Moloi $(\mathbb{D}$ \\ School of Accounting, Auckland Park, P.O. Box 524, University of Johannesburg, 2006 Johannesburg, \\ South Africa; smoloi@uj.ac.za \\ * Correspondence: dmhlanga67@gmail.com
}

Received: 6 May 2020; Accepted: 22 June 2020; Published: 9 July 2020

\begin{abstract}
The study sought to assess the influence of the COVID-19 pandemic in motivating digital transformation in the education sector in South Africa. The study was premised on the fact that learning in South Africa and the rest of the world came to a standstill due to the lockdown necessitated by COVID-19. To assess the impact, the study tracked the rate at which the Fourth Industrial Revolution (4IR) tools were used by various institutions during the COVID-19 lockdown. Data were obtained from secondary sources. The findings are that, in South Africa, during the lockdown, a variety of 4IR tools were unleashed from primary education to higher and tertiary education where educational activities switched to remote (online) learning. These observations reflect that South Africa generally has some pockets of excellence to drive the education sector into the 4IR, which has the potential to increase access. Access to education, particularly at a higher education level, has always been a challenge due to a limited number of spaces available. Much as this pandemic has brought with it massive human suffering across the globe, it has presented an opportunity to assess successes and failures of deployed technologies, costs associated with them, and scaling these technologies to improve access.
\end{abstract}

Keywords: COVID-19; digital transformation; education; 4IR; South Africa

\section{Introduction}

According to Sansa [1], COVID-19 is the novel coronavirus which goes with the name severe respiratory syndrome coronavirus-2 (SARS-COV-2). Scientists have associated this virus with the disease referred to as COVID-19, and it was first identified in China in Wuhan City at the end of 2019 [1]. Before the outbreak of the COVID-19 pandemic, the world was dealing with the learning crisis, evidenced by high levels of learning poverty [2]. The spread of COVID-19, among several disruptions to normal life, necessitated more than 160 countries to effect temporary closure of schools. The World Bank [2] estimates that the closure of schools has left 1.6 billion children and youth out of school. In South Africa, the government was forced to enact a national lockdown, which meant that there was total closure of all schools, including universities. This caused a halt to the learning process. There is concern among some in society that the widespread school closures would lead not only to loss of learning, but also loss of human capital and diminished economic opportunities in the long run [3].

Across the world, governments have brought forth some mitigation measures, such as utilizing remote learning to manage and cope with the crisis [2]. Accordingly, the World Bank is working effectively with many countries to offer support to the efforts currently being implemented by many Ministries of Education to offer remote learning opportunities at the time schools are closed [2]. Further, many organizations are partnering with the World Bank to provide mechanisms for the provision 
of remote learning using various information communication tools. These organizations include, among others:

- mEducation Alliance;

- UNESCO;

- Learning Keeps Going US consortium; and

- Inter-Agency Network for Education in Emergencies and Commonwealth of Learning [4].

Since COVID-19 is a new occurrence, there has not been work that has investigated the rollout and adoption of online learning platforms in the education sector during the pandemic. As such, the question that still needs to be answered is: "What is the effect of COVID-19 in speeding up a digital revolution for education?" With this article, the authors investigate the influence of COVID-19 in speeding up the use of the 4IR tools as a platform for providing learning. The paper is organized as follows. Section 1 provides a background of the 4IR and the tools available for use in the education sector. A brief description of the education sector in South Africa follows. This is then followed by the literature review and background of COVID-19. The outline of the methodology, the results, discussion, and policy recommendation are provided last.

\subsection{The Fourth Industrial Revolution}

4IR is described by Davis [5] as "the advent of cyber-physical systems involving entirely new capabilities for people and machines". Accordingly, Davis [5] observed that, while these capabilities are reliant on the technologies and infrastructure of the third industrial revolution, 4IR represents entirely new ways in which technology becomes embedded within societies and even our human bodies [5,6]. It is in this regard that the 4IR definition makes references to the blurring of lines between InfoTech and biotech. Given this blurring of lines, 4IR is defined as "the fusion of technologies that is blurring the lines between the physical, digital, and biological worlds" [5,7]. 4IR is affecting almost every facet of our daily life, impacting how individuals relate to technology and changing how and where work is done [7-9]. This revolution builds on the third industrial revolution, but it puts together technologies from the digital, physical, and biological worlds [5].

With the changes brought forth by 4IR, the World Economic Forum (WEF) estimated that $65 \%$ of children entering primary schools today will end up working in entirely new occupations or jobs that do not exist now [9]. In most cases, 4IR has been viewed as a threat to jobs as well as the ordinary way of doing things [5]. This creates a risk [5]. Some have argued that organizations were not ready for 4IR. With the emergence of the COVID-19 pandemic, many organizations were forced to completely shut down or reconsider the use of 4IR tools to carry on with their business. There are various technologies that power the 4IR concept [10]. These technologies include, among others, artificial intelligence and robotics; ubiquitous linked sensors; virtual and augmented realities; additive manufacturing; blockchain and distributed ledger technology; advanced materials and nanomaterials; energy capture, storage, and transmission; and new computing technologies, biotechnologies, geoengineering technologies, neurotechnology, and space technologies [11,12].

The above is a collection of technologies driving the fourth industrial revolution today. Um J-S [11] argued that another way to appreciate the fourth industrial revolution is to know the technologies driving this revolution. The tools include but are not limited to those listed above. Um J-S [11] gave the following list of technologies: artificial intelligence and robotics, ubiquitous linked sensors, virtual and augmented realities, additive manufacturing, blockchain and distributed ledger technology, and advanced materials and nanomaterials, among many others. 4IR is at a nascent stage [13]. However, it is expected that some organizations may not have adopted it. Universities and ordinary schools that did not have 4IR tools in place had to shut down at the start of the lockdown necessitated by COVID-19 because there was no preparation for such an event. This is expected to be a common feature in the African continent due to infrastructural challenges, broadband, and the cost of data. In South Africa, 
the lockdown affected the majority of public schools, particularly those that are in the townships and rural areas of the country due to 4IR infrastructural challenges.

\subsection{The Education Sector in South Africa}

The education sector in South Africa is governed by two national departments, namely the Department of Basic Education (DBE), which is responsible for primary and secondary schools, and the Department of Higher Education and Training (DHET), which is responsible for tertiary education and vocational training [14]. Before 2009, these two departments were one, the Department of Education. The DBE department is responsible for public schools, private schools (also referred to by the department as independent schools), early childhood development (ECD) centers, and special needs schools. Public schools and private schools are collectively known as ordinary schools and comprise roughly $97 \%$ of schools in South Africa. The DHET is responsible for education and training (FET) colleges, adult basic education and training (ABET) centers, and higher education (HE) institutions [15].

South Africa has nine provinces: The Free State Province, Limpopo Province, Kwazulu Natal Province, the Eastern Cape Province, the Western Cape Province, the Northern Cape Province, the Gauteng Province, Mpumalanga Province, and the North West Province. These have provincial education departments that are responsible for implementing the policies of the national department, as well as dealing with local issues [16].

\subsection{COVID-19 in South Africa}

As outlined in the Introduction, COVID-19 was first identified in the Hubei Province, City of Wuhan, China in the latter part of $2019[1,17]$. Soon after, this disease began to wreak havoc and the devastating effect of the pandemic forced the World Health Organization (WHO) to declare it as a global pandemic [17]. In South Africa, the first confirmed case of COVID-19 was recorded on 5 March 2020. The fear of the predicted rate at which the pandemic was to infect people motivated the South African government to declare this pandemic a national state of disaster in terms of the Disaster Management Act [18]. The national state of disaster declared on 15 March 2020 by the President of South Africa Cyril Ramaphosa initially contained partial travel bans, travel advisories, discouraging public transport, the closing of schools, and prohibiting gatherings of more than 100 people. Subsequently, on 23 March 2020, President Ramaphosa instituted a national lockdown that would last for 21 days from 26 March 2020 to 16 April 2020 [18]. The lockdown meant that among other organizations that would immediately close were schools and all institutions of higher learning. On 9 April 2020, the President of South Africa announced that the lockdown would be extended by a further 14 days [19].

With the national lockdown, it would mean that the academic calendar for the year 2020 would be affected. To reduce the extent of academic disruptions, several learning institutions responded by moving some of the courses to their online platforms. For basic education, some Non-Governmental Organizations made learning materials available.

\subsection{A Brief Review of the Literature on COVID-19}

The evidence provided in the literature indicates that the source of the COVID-19 is animals and the virus spread in the form of human to human transmission [1]. Sansa [1] stated that COVID-19 is transmitted through respiratory droplets that human beings sneeze, cough, or exhale. The literature on the influence of COVID-19 on the use of 4IR tools is still limited. McKibbin [20], in the article 'the global macroeconomic impacts of COVID-19: Seven scenarios', argued that the evolution of COVID-19 is uncertain, making it difficult for policymakers to formulate an appropriate macroeconomic policy response. In efforts to understand possible economic outcomes of COVID-19, McKibbin [20] explored seven different scenarios of how COVID-19 might evolve in the coming year using a modeling technique. The technique examines the impacts of different scenarios on macroeconomic outcomes and financial markets in a global hybrid DSGE/CGE general equilibrium model. The study found that, 
even though the pandemic is contained, it could significantly impact the global economy in the short run. These scenarios demonstrate the scale of costs that might be avoided by greater investment in public health systems in all economies, but particularly in less developed economies where health care systems are less developed and population density is high.

Baldwin [21] also discovered COVID-19 has both supply-side shocks and demand shocks. The author went on to argue that both aspects will have an impact on international trade in goods and services. Atkeson [22], in the study "What Will Be the economic impact of COVID-19 in the US?", introduced a simple SIR model to economists on progression of COVID-19 in the United States over the next 12-18 months. The model was built on the SIR model of the Markov model of the spread of an epidemic in a population where the total population is divided into categories of being susceptible to the disease (S), actively infected with the disease (I), and recovered (or dead), and no longer contagious (R). In the model, how an epidemic plays out over time is determined by the transition rates among these three states. The model allowed for quantitative statements regarding the trade-off between the severity and timing of suppression of the disease through social distancing and the progression of the disease in the population.

Wenham [23] found that "there was gender analysis of the outbreak by global health institutions or governments in affected countries". Wenham [23] went further to argue that the closure of schools to control COVID-19 transmission in China, Hong Kong, Italy, South Korea, and beyond might have a differential effect on women, who provide most of the informal care within families, with the consequence of limiting their work and economic opportunities.

\section{Materials and Methods}

The study mainly used the literature review approach, including document analysis and conceptual analysis of secondary sources of data, which included several peer-reviewed journals, reports, and even newspaper articles. The study benefited from recently published journals, policy, and reports from national and international organizations on COVID-19 and 4IR. The conceptual nature of the article presents a particular limit due to the limited nature of data and the fact that both 4IR and COVID-19 are current events.

Table 1 gives an estimated number of the journal articles, reports, and news articles that helped to shape the direction of the study. Some of the journal reports and news articles listed in the table are not necessarily referenced in the paper, as they only contributed to ideas that led to the development of the paper. The numbers of journals, reports, and newspaper articles listed are estimates; they could be more.

Table 1. Journal articles, reports, and news articles that shaped the trajectory of the study.

\begin{tabular}{ccc}
\hline Journal Articles & Reports & News Articles \\
\hline 33 & 23 & 29 \\
\hline \multicolumn{3}{c}{ Source: Authors' Analysis. }
\end{tabular}

\section{Results and Discussion}

\subsection{The Impact of COVID-19 on Digital Transformation towards the 4IR}

The outbreak of COVID-19 came as a wake-up call to the education sector in South Africa, for primary, secondary, and tertiary education. We argue that it will be difficult for the education sector to go back to the old ways of teaching, as the issues of social distancing will remain active for a while to prevent the spread of the virus. Discussions around online learning and the use of television and radio for revision began to occupy the corridors of the education sector as soon as the reality of lockdown struck. As such, several responses have been mounted by various organizations to mitigate against the loss of time because of the lockdown. We are of the view that this pandemic has acted as a motivating factor towards digital transformation in the education sector during the lockdown. In this regard, 
to determine how the sector has responded to the pandemic to ensure that learning continues, we have extracted some of the tools used by the sector during the lockdown. These are presented in different categories as indicated in the discussions below. The tables try to demonstrate the 4IR technologies used in South Africa during the lockdown. These technologies were used in various platforms created by various private institutions in partnership with the government of South Africa to combat the effects of COVID-19 on education.

\subsection{Digital Transformation towards $4 I R$ in the Education Sector in South Africa during the Lockdown}

\subsubsection{Virtual Learning during the Lockdown}

Table 2 below shows the tools used by the department of education in South Africa to provide virtual classes during the lockdown. The department made use of television and radio stations to offer virtual lessons exclusively to pupils during the lockdown. This was a response to the disturbances brought by COVID-19 in the country. As shown in the table, pupils received lessons from SABC television and radio, DSTV, and E.tv stations.

Table 2. Virtual classes during the lockdown.

\begin{tabular}{cccccc}
\hline Tools Used & Description & Connectivity & Platform & Conditions of Use & $\begin{array}{c}\text { Target } \\
\text { Group }\end{array}$ \\
\hline $\begin{array}{c}\text { Television } \\
\text { (SABC, DSTV, } \\
\text { E.tv) }\end{array}$ & $\begin{array}{c}\text { Teachers } \\
\text { delivering } \\
\text { lessons live to } \\
\text { learners on TV }\end{array}$ & Offline & $\begin{array}{c}\text { Television } \\
\text { Desktop }\end{array}$ & Free(lockdown) & $\begin{array}{c}\text { Primary } \\
\text { Secondary }\end{array}$ \\
\hline Radio (SABC) & $\begin{array}{c}\text { Teachers } \\
\text { deliver lessons } \\
\text { live to learners }\end{array}$ & Offline & Radio/desktop & Free(lockdown) & $\begin{array}{c}\text { Primary } \\
\text { Secondary }\end{array}$ \\
\hline
\end{tabular}

Source: Authors' Analysis.

As presented above, the government of South Africa and various sections of its media made some provisions for virtual learning. The ministry of communication and digital technologies led the initiative. Through the minister, an announcement was made that the departments of communications and digital technologies and basic education had joined forces, to ensure virtual learning is a reality during the nation-wide lockdown [24,25]. This move was necessitated by both the closure of schools during the lockdown and the desire to mitigate the impact of COVID-19 on the education sector. The other reason is that the country was not prepared for the disruption, and as a result bringing in virtual classes was a way to find possible ways that technology could help address the disruption induced by COVID-19 [24,25].

In this initiative, the public broadcaster (the South African Broadcasting Corporation) and DSTV channel 180 availed channels entirely dedicated to education $[19,26]$. In addition to that, the national broadcaster added two studios where the broadcast of the virtual classrooms would take place. In these studios, teachers were delivering lessons live and real time to learners. This was done through virtual classrooms, teaching learners as they would in a classroom. Through E.tv, the government also allocated a dedicated channel for three months on the open view platform for learners $[19,26,27]$. Further to the initiatives above, the government availed, broadcast of lessons on community radio stations around the country. The use of radio and television to introduce virtual classes necessitated by COVID-19 in South Africa demonstrates that South Africa is capable of transforming the education sector towards the 4IR.

\subsubsection{Use of Zero-Rated Applications and Educational Websites}

Table 3 indicates that, because of COVID-19, the government of South Africa went into partnership with private network providers to offer zero-rated applications and educational websites. An application 
or website is defined as zero-rated when a mobile operator does not count the usage of the application or website against a user's monthly data allotment, which renders its use as effectively free [27]. Various network providers, such as Vodacom, Cell C, and MTN, provided these applications and websites. These applications and websites were used frequently by students from various Universities in South Africa.

Table 3. Use of free zero-rated applications and educational websites.

\begin{tabular}{cccccc}
\hline Tools Used & Description & Connectivity & Platform & $\begin{array}{c}\text { Conditions } \\
\text { of Use }\end{array}$ & $\begin{array}{c}\text { Target } \\
\text { Group }\end{array}$ \\
\hline $\begin{array}{c}\text { Mobile } \\
\begin{array}{c}\text { Platforms and } \\
\text { applications } \\
\text { (Vodacom, Cell } \\
\text { C, MTN) }\end{array}\end{array}$ & $\begin{array}{c}\text { Learners access } \\
\text { learning material from } \\
\text { educational and } \\
\text { informational } \\
\text { (reference) websites }\end{array}$ & Online & $\begin{array}{c}\text { Desktop/ } \\
\text { laptop/ } \\
\text { mobile }\end{array}$ & $\begin{array}{c}\text { Free } \\
\text { (lockdown) }\end{array}$ & $\begin{array}{c}\text { Primary/ } \\
\text { secondary/ } \\
\text { tertiary }\end{array}$ \\
\hline
\end{tabular}

Source: Authors' Analysis.

The other platform used to ensure that learning progressed smoothly were zero-rated applications and websites. The government of South Africa indicated that electronic readers were available via all platforms of major cell phone networks in South Africa, i.e., Vodacom, MTN, Telkom, and Cell-C, as well as 2Enable App as a freely downloadable educational platform with more than 2000 electronic readers in the indigenous languages of the country $[18,19,26]$. Besides, it was reported that, in the days after the President's first announcement of measures to combat the spread of the coronavirus on 15 March 2020, many schools had successfully taken the curricular online. As such, for many students, it was back to school that week, albeit from home $[25,28]$.

To successfully execute the task at hand, teachers created lesson plans, activities, and assignments to ensure that students did not miss out on crucial learning during the lockdown [28]. These materials were available and accessed online. In addition to that, South Africa's mobile networks gave room to students across the educational divide to access teaching materials through zero-rated educational and informational (reference) websites [28]. The government also indicated that they would also promote the African Storybook series through the 2Enable App [19].

It is interesting to note that, a few days into the lockdown in South Africa, data traffic surged between $35 \%$ and $60 \%$, as reported in almost all local networks $[27,28]$. Mobile networks dropped data costs. However, due to poverty, which limits access, some pupils were still not able to have access. The introduction of electronic readers for pupils via online platforms in partnership with Vodacom, MTN, Telkom, and Cell C made it possible for pupils to have access [18]. As reported by the department of education (DBE), pupils were also gaining free access to Siyavula Maths and Science support provided in partnership with MTN [29]. The government noted with concern that, even though mobile network operators in the country had started to drop data costs, some in the country were unable to access the rich content that had been made available, due to issues of broadband access or network capacity $[19,25]$. We see the extensive use of zero-rated applications and websites during the lockdown as a building block towards pushing the education towards 4IR.

\subsubsection{Lunching of STEM Lockdown Digital School and Use of Social Media Applications}

As indicated in Table 4, in response to the COVID-19 disturbances, Sasol Foundation (SF) and the African Teen Geeks came up with a STEM lockdown digital school and there was wide use of the social media applications associated with the digital school. 
Table 4. Use of Social Media Apps and the Introduction of STEM lockdown digital school (Sasol Foundation (SF) and African Teen Greeks).

\begin{tabular}{|c|c|c|c|c|c|}
\hline Tools Used & Description & Connectivity & Platform & $\begin{array}{c}\text { Conditions } \\
\text { of Use }\end{array}$ & $\begin{array}{l}\text { Target } \\
\text { Group }\end{array}$ \\
\hline $\begin{array}{c}\text { Internet } \\
\text { (website), (Ms } \\
\text { Zora, SF, } \\
\text { Siyavula, DBE) }\end{array}$ & $\begin{array}{l}\text { Teachers in public and } \\
\text { private schools offer } \\
\text { classes through a } \\
\text { live stream }\end{array}$ & Online & $\begin{array}{l}\text { Desktop } \\
\text { laptop } \\
\text { mobile }\end{array}$ & $\begin{array}{c}\text { Free } \\
\text { (Lockdown) }\end{array}$ & $\begin{array}{l}\text { Primary } \\
\text { Secondary }\end{array}$ \\
\hline $\begin{array}{c}\text { Facebook (Ms } \\
\text { Zora) }\end{array}$ & $\begin{array}{l}\text { Teachers in public and } \\
\text { private schools offer } \\
\text { classes through a } \\
\text { live stream }\end{array}$ & Online & $\begin{array}{l}\text { Desktop } \\
\text { Laptop } \\
\text { Mobile }\end{array}$ & $\begin{array}{c}\text { Free } \\
\text { (lockdown) }\end{array}$ & $\begin{array}{l}\text { Primary } \\
\text { Secondary }\end{array}$ \\
\hline $\begin{array}{c}\text { Twitter (Ms } \\
\text { Zora) }\end{array}$ & $\begin{array}{l}\text { Teachers in public and } \\
\text { private schools offer } \\
\text { classes through a } \\
\text { live stream }\end{array}$ & Online & $\begin{array}{l}\text { Desktop } \\
\text { Laptop } \\
\text { mobile }\end{array}$ & $\begin{array}{c}\text { Free } \\
\text { (lockdown) }\end{array}$ & $\begin{array}{l}\text { Primary } \\
\text { Secondary }\end{array}$ \\
\hline
\end{tabular}

Source: Authors' Analysis.

The COVID-19 pandemic took the education sector by surprise. Even though the Department of Basic Education had been implementing digital technology, the process was slow. However, immediately after the lockdown, the Department of Basic Education launched a STEM lockdown digital school in partnership with the non-profit coding organization Africa Teen Geeks. On the other hand, the Sasol Foundation introduced a free science, technology, engineering, and mathematics (STEM) Lockdown Digital School, through the artificial-intelligence-based educational platform Ms Zora [30,31]. The programs enrolled more than 34 teachers who worked in both public and private schools to offer classes through a live stream on Africa Teen Geeks' social media pages, Facebook, Twitter, Ms Zora, and the DBE website [32]. A lecturer from the University of Witwatersrand's Department of Occupational Therapy, Amanda Calitz, supervised the program [25,31]. The program offered lessons for Grades R-12. The good part of the programs was that these programs were being offered at no cost and the sessions were being recorded and posted on the DBE website so that students would have access at all times [30,32]. With this program, pupils were able to access lessons on websites, and on social media freely. However, the greatest challenge remained the targeting of learners in rural areas, especially those without access to the Internet. The nature of the 4IR revolution, which represents the fusion of technologies in the physical, digital, and biological worlds, unleashing of the 4IR tools to combat the effects of COVID-19 in the rural areas was practically difficult due to a number of challenges related to poor internet connectivity, and the general state of infrastructure [5,24].

Even with these challenges, we are of the view that the introduction of this STEM lockdown digital classroom in a way motivated the authorities towards the digitalization of the education sector. The important aspect is for the system to be maintained after the lockdown. This could be done following an extensive analysis of the performance of these programs after the lockdown.

\subsubsection{Switching to Remote Learning Online}

The extensions of the lockdown in South Africa forced universities and other institutions of higher learning to switch exclusively to remote learning. Table 5 describes some of the tools employed in the process. 
Table 5. Exclusive Online Learning-Remote Learning.

\begin{tabular}{|c|c|c|c|c|c|}
\hline Tools Used & Description & Connectivity & Platform & $\begin{array}{c}\text { Conditions } \\
\text { of Use }\end{array}$ & $\begin{array}{l}\text { Target } \\
\text { Group }\end{array}$ \\
\hline $\begin{array}{c}\text { Internet } \\
\text { (Websites) } \\
\text { YouTube (Most } \\
\text { universities) }\end{array}$ & $\begin{array}{l}\text { Leaners Learn on } \\
\text { their own at home }\end{array}$ & Online & $\begin{array}{l}\text { Desktop/ } \\
\text { Laptop/ } \\
\text { Mobile }\end{array}$ & $\begin{array}{l}\text { All rights } \\
\text { reserved }\end{array}$ & $\begin{array}{l}\text { Tertiary/ } \\
\text { primary/ } \\
\text { secondary }\end{array}$ \\
\hline $\begin{array}{l}\text { Microsoft } \\
\text { Teams }\end{array}$ & $\begin{array}{l}\text { Used mainly by } \\
\text { staff and learners in } \\
\text { tertiary institutions } \\
\text { to hold discussions }\end{array}$ & Online & $\begin{array}{l}\text { Desktop/ } \\
\text { Laptop/ } \\
\text { mobile }\end{array}$ & Freemium & Tertiary \\
\hline Skype & $\begin{array}{l}\text { Used mainly by } \\
\text { staff and learners in } \\
\text { tertiary institutions } \\
\text { to hold discussions }\end{array}$ & Online & $\begin{array}{l}\text { Desktop/ } \\
\text { Laptop/ } \\
\text { Mobile }\end{array}$ & $\begin{array}{l}\text { Freemium/ } \\
\text { All rights } \\
\text { reserved }\end{array}$ & Tertiary \\
\hline $\begin{array}{l}\text { WhatsApp } \\
\text { groups }\end{array}$ & $\begin{array}{l}\text { Used mainly by } \\
\text { staff and learners in } \\
\text { tertiary institutions } \\
\text { to hold discussions }\end{array}$ & Online & $\begin{array}{l}\text { Desktop/ } \\
\text { Laptop } \\
\text { mobile }\end{array}$ & $\begin{array}{l}\text { All rights } \\
\text { reserved }\end{array}$ & Tertiary \\
\hline Zoom & Group discussions & Online & Desktop & Freemium & Tertiary \\
\hline
\end{tabular}

Source: Authors' Analysis.

The reality of the lockdown has forced many institutions of higher learning to switch to online learning. Several universities in South Africa switched to online learning even though some universities did not officially announce the move. For instance, the University of Johannesburg, the University of Cape Town and the University of Pretoria announced to their students that they would conduct learning online in their second semester to ensure social distance [33]. We see this change as the beginning of the process that will move education to 4IR where learning will be mostly digital, with a few occasions of face-to-face engagements.

Apart from what the Universities are doing with regards to online learning, the Department of Basic Education has also published study material including textbooks, worksheets, revision booklets, and study guides on their website. In Cape Town, organizations joined the effort to offer free online learning for school pupils during the lockdown. Organizations such as Worksheet Cloud, together with My School My Village My Planet provided funding for this program [32].

Lessons called Worksheet Cloud Live Lessons were free and were offered to Grades 3-7. The lessons were for mathematics, English, and natural science. In these lessons, students were enjoying unlimited and free access to live-streamed online classrooms every day. Parents could easily, and freely, have access to learning material for their children. There were many other useful sights for students where they were able to study online, for instance the Vodacom e-school, the Department of Basic Education website, Olico Maths education, Gauteng department of education, and IXL [32].

Efforts to intensify online learning had already been there in the education sector in South Africa before the pandemic. In October 2019, the Gauteng Department of Education (GDE) officially launched its digital content and online assessment platform. The platform aimed to increase access to digital content as well as enhance opportunities for continuous assessment activities to support curriculum delivery in ICT-enabled schools. However, the process was changed with the pandemic and the GDE enhanced this further to reach partnership agreements with DStv, Vodacom, and Telkom to broadcast various school lessons during the lockdown period [33-35]. The GDE improved online learning through various mechanisms, which include the DStv partnership where mind-set on channel 318 offered lessons to all other grades except Grades 4-9, and a pop-up channel on 317 that was responsible for carrying learning content for Grades 4-9 $[19,26]$. In reality, we are of the view that COVID-19 has transformed the mode of teaching in the education sector during the lockdown. Tertiary institutions are now intensifying their efforts towards providing online learning using YouTube, Microsoft teams, 
Zoom, Skype, WhatsApp, and DStv. This study shows that COVID-19 has had a great influence on the education sector's use of various 4IR tools.

\section{Conclusions}

In this study, secondary research was done to understand the impact of COVID-19 in influencing the digital transformation in the education sector. In essence, the study investigated how the education sector adopted the use of 4IR tools during the COVID-19 lockdown period. The study was based on the reviewing of secondary data sources; these were mainly newspaper articles, magazines, peer-reviewed journals, recently published journal articles, and policy reports from national and international organizations. Our finding is that, during the lockdown, the South African education sector massively adopted different 4IR tools (digital transformation) from primary education to higher and tertiary education. The lockdown motivated the creation of virtual learning, the use of zero-rated applications and educational websites, launching of STEM lockdown digital school, and, finally, the sector generally switched to remote learning (online learning). This suggests that, during the lockdown, various 4IR tools were unleashed for primary education to higher and tertiary education where educational activities switched to remote learning (online learning).

The observations above point to the fact that South Africa generally has some pockets of excellence to drive the education sector into the 4IR, which has the potential to increase education access. Access to education, particularly at higher education level, has always been a challenge due to a limited number of spaces. Much as this pandemic has brought massive human suffering across the globe, it presents an opportunity to assess successes and failures of deployed systems, costs associated with them, and scaling this to improve access.

As a result, the government of South Africa should propose mechanisms of fiscal expansion to try to provide funding for moving of some aspects of education online and promoting the adoption of the 4IR. An in-depth analysis of the strengths and weaknesses of the systems put in place during the lockdown should be conducted. This could be accompanied by a cost-benefit scenario analysis of each technology adopted as a stopgap measure during the lockdown.

Author Contributions: Conceptualization, D.M. Formal analysis, D.M. and T.M.; Supervision, T.M.; Validation, T.M.; Writing—original draft, D.M.; Writing—review \& editing, T.M. All authors have read and agreed to the published version of the manuscript.

Funding: This research received no external funding.

Acknowledgments: We would like to extend our appreciation to the University of Johannesburg and the Department of Accountancy for the administrative support for the work to be completed.

Conflicts of Interest: The authors declare no conflict of interest.

\section{References}

1. Sansa, N.A. Analysis of the Impact of the Covid-19 to the Petrol Prices in China. Divers. J. Multidiscip. Res. 2020, 2. [CrossRef]

2. The World Bank Education Global Practice. Guidance Note: Remote Learning \& COVID-19; The World Bank: Washington, DC, USA, 2020; pp. 1-4.

3. The World Bank. Rapid Response Briefing Note: Remote Learning and COVID-19 Outbreak; The World Bank: Washington, DC, USA, 2020; pp. 1-10.

4. The World Bank. Remote Learning, Distance Education and Online Learning During the COVID19 Pandemic: A Resource List by the World Bank's Edtech Team; The World Bank: Washington, DC, USA, 2020; pp. 1-44.

5. Davis, N. What Is the Fourth Industrial Revolution? World Economic Forum: Geneva, Switzerland, 2016; p. 11. Available online: https://www.weforum.org/agenda/2016/01/what-is-the-fourth-industrial-revolution/ (accessed on 5 May 2020).

6. Shava, E.; Hofisi, C. Challenges and Opportunities for Public Administration in the Fourth Industrial Revolution. Afr. J. Public Aff. 2017, 9, 203-215. 
7. Deloitte Global Business Coalition For Education. Preparing Tomorrow's Workforce for the Fourth Industrial Revolution; Deloitte: London, UK, 2018; pp. 1-58. Available online: https://www.voced.edu.au/content/ngv: 85595 (accessed on 5 May 2020).

8. Schwab, K. Davos Manifesto 2020: The Universal Purpose of a Company in the Fourth Industrial Revolution. 2019. World Economic Forum Web Site. Available online: http://www.worldacademy.org/files/global_ leadership/papers/Davos_Manifesto_2020.pdf (accessed on 5 May 2020).

9. Schwab, K. Why We Need the “Davos Manifesto" for a Better Kind of Capitalism. 2019. World Economic Forum Web Sit. Available online: https://www.weforum.org/agenda/2019/12/why-we-need-the-davosmanifesto-for-better-kind-of-capitalism/ (accessed on 5 May 2020).

10. Jonah, C.M.P.; May, J.D. Evidence of the existence of socioeconomic-related inequality South African diets: A quantitative analysis of the 2017 General Household Survey. World Nutr. 2019, 10, 27-42. [CrossRef]

11. Um, J.-S. Introduction to the Fourth Industrial Revolution. In Drones as Cyber-Physical Systems; Springer: Singapore, 2019; pp. 1-20.

12. Schwab, K. The fourth industrial revolution. Acad. J. Manuf. Eng. 2016, 14, 5.

13. Soh, C.; Connolly, D. New Frontiers of Profit and Risk: The Fourth Industrial Revolution's Impact on Business and Human Rights. New Political Econ. 2020. [CrossRef]

14. Green, W. Foundation phase teacher provision by public higher education institutions in South Africa. S. Afr. J. Child. Educ. 2011, 1, 1. [CrossRef]

15. Ntombela, S. The progress of inclusive education in South Africa: Teachers' experiences in a selected district, KwaZulu-Natal. Improv. Sch. 2011, 14, 5-14. [CrossRef]

16. Mes, R.; Singh, P. Continuing professional development for principals: A South African perspective. S. Afr. J. Educ. 2007, 27, 477-490.

17. Mhlanga, D.; Ndhlovu, E. Socioeconomic Implications of the COVID-19 for Smallholder Livelihoods in Zimbabwe. 2020. Available online: www.preprints.org (accessed on 5 May 2020).

18. South African Government. Minister Angie Motshekga on Basic Education Sector Plans to Support Learners during Coronavirus COVID-19 Lockdown. 2020; South African Government, Department of Education Web Site. Available online: https://www.gov.za/speeches/minister-angie-motshekga-basic-education-sectorplans-support-learners-during-covid-19 (accessed on 5 May 2020).

19. Government of South Africa. Minister Angie Motshekga: Basic Education Sector Recovery Plans for the Reopening of Schools, Following the Coronavirus COVID-19 Lockdown Adjustment of Regulations. 2020; South African Government Web Site. Available online: https:/www.gov.za/speeches/minister-angiemotshekga-basic-education-sector-recovery-plans-reopening-schools-following (accessed on 5 May 2020).

20. McKibbin, W.J.; Fernando, R. The Global Macroeconomic Impacts of COVID-19: Seven Scenarios. SSRN Electron. J. 2020. [CrossRef]

21. Baldwin, R.; di Mauro, B.W. Economics in the Time of COVID-19; CEPR Press: London, UK, 2020; pp. 105-109. Available online: www.cepr.org (accessed on 5 May 2020).

22. Atkeson, A.; Hall, B. What Will Be the Economic Impact of COVID-19 in the US? Rough Estimates of Disease Scenarios. 2020. Available online: https://www.minneapolisfed.org/research/staff-reports/what-will-be-theeconomic-impact-of-covid-19-in-the-us-rough-estimates-of-disease-scenarios (accessed on 5 May 2020).

23. Wenham, C.; Smith, J.; Morgan, R. COVID-19: The gendered impacts of the outbreak. Lancet 2020, 395, 846-848. [CrossRef]

24. ITWeb. Overcoming the Educational Digital Divide as SA Grapples with a Deadly Global Pandemic. 2020. Available online: https://www.itweb.co.za/content/6GxRKqYJk35vb3Wj (accessed on 5 May 2020).

25. Mhlanga, D.; Moloi, T. COVID-19 and the Digital Transformation of Education: What We Are Learning in South Africa. 12 April 2020. Available online: www.preprints.org (accessed on 5 May 2020).

26. SABC. SABC Education-Virtual Teaching Becomes a Reality through New Education Technology. 2020. SABC Web Site. Available online: http://sabceducation.co.za/news-module/3583-virtual-teaching-becomesa-reality-through-new-education-technology (accessed on 5 May 2020).

27. ITWeb. The Government Makes Provision for Virtual Learning during Lockdown. 2020. Available online: https://www.itweb.co.za/content/Gb3BwMW8LQKq2k6V (accessed on 5 May 2020).

28. Tech Financials. Coronavirus: Overcoming the Educational Digital Divide in South Africa. 2020. Available online: https:/techfinancials.co.za/2020/04/02/coronavirus-overcoming-the-educational-digitaldivide-in-south-africa/ (accessed on 5 May 2020). 
29. Department of Education, Government of South Africa (2020). Minister Angie Motshekga on Basic Education Sector Plans to Support Learners during Coronavirus COVID-19 Lockdown. Available online: https://www.gov.za/speeches/minister-angie-motshekga-basic-education (accessed on 8 April 2020).

30. Africa Teen Geeks. ATG, DBE and Sasol Foundation Presents FREE STEM Lockdown Digital School. Available online: https:/www.africateengeeks.co.za/press/8/lockdown-digital-school-press-release (accessed on 5 May 2020).

31. City Press. STEM Digital School Launched, Teachers Required for e-Learning during Lockdown. 2020. City Press Web Site. Available online: https://city-press.news24.com/News/stem-digital-school-launchedteachers-required-for-e-learning-during-lockdown-20200402 (accessed on 5 May 2020).

32. ILO. SA Learners Gain Access to Unlimited and Free Online Education during Lockdown. 2020. Available online: https://www.iol.co.za/technology/software-and-internet/sa-learners-gain-access-tounlimited-and-free-online-education-during-lockdown-45891281 (accessed on 5 May 2020).

33. Universities South Africa. Public Universities Are Readying Themselves for Virtual Teaching and Learning during the National Lockdown. 2020. Universities South Africa Web Site. Available online: https: //www.usaf.ac.za/universities-coronavirus-covid-19-updates/ (accessed on 5 May 2020).

34. Moloi, T. Decoding risk management practices in the South African Public Service: A focus on national government departments. Afr. J. Bus. Econ. Res. 2016, 11, 17-43.

35. Moloi, T.; Marwala, T. Artificial Intelligence in Economics and Finance Theories; Springer: Berlin, Germany, 2020; ISBN 978-3-030-42961-4.

(C) 2020 by the authors. Licensee MDPI, Basel, Switzerland. This article is an open access article distributed under the terms and conditions of the Creative Commons Attribution (CC BY) license (http://creativecommons.org/licenses/by/4.0/). 